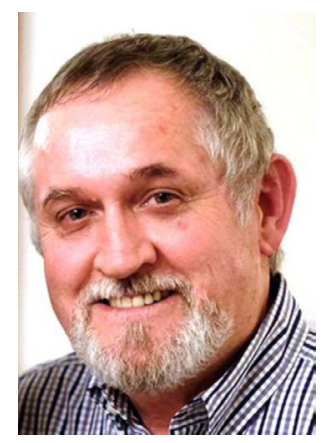

\author{
Cliff Rosendahl $^{1}$, N. Kiladze ${ }^{2}$, T. Shulaia ${ }^{3}$ \\ ${ }^{1}$ The University of Queensland, Brisbane, Australia \\ ${ }^{2}$ Tbilisi State Medical University \\ ${ }^{3}$ Medical Center "Marjani"
}

\title{
Non-melanoma Skin Cancers in Uranium Miners - Clinical Cases
}

Introduction. Using sources of ionizing radiation in various spheres of human life has become an integral part of the existence of modern society and the necessary condition for further scientific and technological progress. However, along with the obvious benefits, this increases the radiation burden and number of malignant neoplasms and the related reduction in life expectancy $[4,6]$.

The various health risks associated with uranium exposure are well known, which mainly concerns the lung cancer, but recently there has been a hypothesis that if uranium is photoactivated by ultraviolet radiation, it may be more dangerous for the skin. This idea is confirmed by statistics on countries with high levels of solar radiation and uranium deposits, which are being actively developed in such countries as Australia, Kazakhstan, Canada, Russia, etc. The following article provides a brief overview of the literature and presents 2 cases of basal cell carcinoma in the miners of the uranium mine.

The aim of the study. To analyze the overview of the accessible literature and the description of two clinical cases of non-melanoma skin cancers in uranium miners from the own practice.

Materials and methods. The content analysis, method of systemic comparative analysis, bibliosemantic method of studying of actual scientific researches concerning the practice of non-invasive methods of evaluation were used. The search for sources was carried out in the scientific meteorological databases: PubMed-NCBI, Medline, CochraneLibrary, EMBASE, ResearchGate by keywords: "uranium miners", "non-melanoma skin cancer", "UV", "dermatoscopy". Digital dermoscopic images were captured using dermatoscope (DermLite DL3 dermatoscope) mounted on a digital camera (Galaxy S-4 Samsung Corporation). Ultrasound gel was also used for immersion dermatoscopy. All images were evaluated using the algorithm of $\mathrm{H}$. Kittler.

Results. Literature review. Skin cancer is the most common malignancy in fair-skinned population and in accordance with the statistical data, the incidence of melanoma has been increasing rapidly worldwide at a widely varied rate among continents and countries. The highest incidence rates of skin cancer have been reported in New Zeeland and Australia, followed by US and Europe. In Europe the highest indices are in Sweden, Switzerland and Great Britain [19]. Kazakhstan and Israel are also among the countries with the high incidence rates $[12,18]$.

Malignant neoplasms are the kind of environmentally indicative pathology, a highly informative and socially significant indicator of the health status of the population as a whole. Among the factors that have a direct or indirect impact on the dynamics and structure of the incidence of tumors should be attributed to environmental factors, including natural, anthropogenic, socio-economic and demographic factors. Exposure to ultraviolet rays is a major risk factor for development of skin cancer but individual risk depends on both constitutional and environmental factors. The constitutional risk factors of skin cancer include family history, red hair color, multiple moles syndrome, sun exposure sensitivity, etc. [10,11], whereas solar ultraviolet (UV) radiation is a well-established environmental risk factor. The exposure to chemicals (polycyclic hydrocarbons derived from the incomplete combustion or distillation of coal or petroleum; inorganic arsenic and photosensitizing agents such as psoralens) and exposure to ionizing radiation are among the environmental factors as well. That is why skin cancers at the same time are also an indicator of the health of the population with a significant degree of dependence on the quality of the environment. The high incidence rate is often seen as a medical indicator of the environmental distress of the territory.

As the statistical data of the oncologic diseases show, the higher incidence rates coincide with countries that also have large uranium reserves - Australia, Kazakhstan, etc. According to the World Uranium Inventories of 2009, the country with the largest uranium reserves is Australia (29.0\%), followed by Kazakhstan (13.0\%), but in 2009 Kazakhstan came in first in the world for extraction of uranium, ahead of Canada [3] and the rate of skin malignant diseases in this country is still growing. 
Natural radionuclides (EPN), being of natural origin, are present in varying amounts in most environmental objects. In the human body most of them come through the respiratory or digestive organs and pose a threat to health. According to UNSCEAR [1994], the largest contribution $(70.0 \%)$ to the total effective dose of population exposure is made by the natural radiation background. The average dose of internal irradiation due to radionuclides of terrestrial origin is about $1.35 \mathrm{mSv}$ per year. The building materials, soil, artesian water and other objects of the natural environment can be the sources of radioactive emissions. The greatest threat to a human is represented by the isotopes of potassium-40, radium-226 and thorium- 232 . It should be noted that the danger to humans is not only uranium-238 and thorium-232, but also their daughter products of decay - radon and thoron. Being radioactive gases at a certain stage of decay, they can be distributed in space and get through the respiratory system into the human body, threatening their health. According to world estimates, radon is the cause of many thousands of deaths per year. Breathing air with the high content of radon, a person risks to get lung cancer. Doctors warn that radon is currently the main (after smoking) cause of lung cancer in all the countries.

The various health risks from natural uranium are well known, but in this report we want to emphasize the relationship between uranium exposure and skin cancer. Similar studies have been conducted in Switzerland, by Vienneau et al. [25].

Environmental Perspectives 125(06)-June 2017 [9] explored the dependence between skin cancer and effects of radon and UV exposure in different population. According to the literature non-melanoma skin cancer is often observed in former uranium miners [24]. Clinical aspects of the effect on the body of uranium compounds have been studied for decades. The earliest works on occupational diseases of workers in uranium mines date back to 1879 . Experimental studies on many types of animals revealed different toxicity of uranium compounds depending on its physical and chemical properties. The highest toxicity, as it turned out, is possessed by soluble compounds of uranium, the least - poorly soluble (oxide-nitrous oxide, dioxide, tetrafluoride, etc. [1].

It is well known that radon is the second-leading cause of lung cancer after smoking, accounting for an estimated $3.0-14.0 \%$ of cases [14]. Subsequently, the skin's outer layer is irradiated by the alpha particles from radon decay [7]. Annual dose to the skin at $200 \mathrm{~Bq} / \mathrm{m} 3$ is estimated to be $25 \mathrm{mSv}$ [8]. As such, the skin receives by far the second-highest dose after the respiratory tract; ranked from the highest to lowest, average doses are 97, 2.9, and $<1 \mathrm{mSv}$ respectively, for the lung, kidney, and all other organs [12].

Radiation impact on the personnel of uranium mines is mainly due to the internal irradiation with radioactive gas radon and the affiliate products of its decay. In addition, external gamma and beta radiation also affects the personnel of the mines. Uranium, as a rule, poses the greatest danger to human health in case of ingestion, inhalation or through cracks in the skin (prolonged contact may also result into the large dose of external irradiation). In the body, uranium poses the threat, being both a toxic heavy metal and a radioactive substance. In addition, there is a number of signs that indicate possible synergism of these two types of effects on the body. The results of experiments and observations in humans show that undamaged skin seems to be an effective barrier for the penetration of transuranic radionuclides into the body. The analysis of injuries in workers of plutonium production showed that all cases of contamination of skin wounds with $\mathrm{Pu}$ can be divided into three categories. For the first category of persons, $\mathrm{Pu}$ is long detained at the wound site after reducing its concentration during the first month by $8-30$ times from the amount received. The second category includes cases of contamination, in which the amount of radionuclides in the wound does not change for a long time, and then decreases to the background level. It is suggested that such dynamics of $\mathrm{Pu}$ level in the skin can be explained by the finding of a radionuclide close to the epidermis; the gradual dying off of its cells leads to skin cleansing. The third category is characterized by the contamination, in which the radionuclide quickly disappears from the wound TB of Pu compounds from the subcutaneous tissue is 28-30 days. The rate of absorption of complex compounds of $\mathrm{Pu}$ from the subcutaneous tissue is $5.0-10.0 \% / \mathrm{h}$, and nitrate $239 \mathrm{Pu} \square 1.0 \% / \mathrm{h}$. The resorption of Pu from muscle tissue obeys the same rules. The absorption of $\mathrm{Pu}$ and other transuranic radionuclides increases dramatically in the case of mechanical, thermal or chemical damage to the skin and they can quickly enter the blood and tissue fluid. The experiments showed that after administration of transuranic radionuclides to the subcutaneous tissue, the critical organs are not only the skeleton and liver, but also the tissues at the injection site. In case of polymer plutonium, high concentrations of the nuclide are also found in the regional lymph nodes [2].

Soluble uranium compounds such as nitrate can be absorbed through the skin [5, 20]. In studies with rabbits, death due to renal failure was observed to occur via this mode of exposure with a lowest LD 50 value of $28 \mathrm{mg}$ $\mathrm{U} / \mathrm{kg}$ as uranyl nitrate in an ethereal solution [20]. Rats and guinea pigs were observed to be significantly less sensitive. In the specific case of acute exposure of animals to uranyl nitrate, penetration into the intracellular space between the granular and horny layers of the skin was observed to occur within a period of 15 minutes; after 48 hours no residual uranium was observed in the skin [5]. These authors considered this to be due to the absorption of uranium into the systemic circulation resulting in weight loss and, in severe cases, death. More recent studies of sub-acute dermal exposure to uranyl nitrate (typical applied concentrations $0.6 \mathrm{~g} / \mathrm{ml}$ uranyl hexahydrate to skin areas of between 0.5 and $16 \mathrm{~cm} \mathrm{2)} \mathrm{by} \mathrm{R.} \mathrm{Lopez} \mathrm{et} \mathrm{al.} \mathrm{[17]}$ confirm the observations of earlier studies of acute exposure. In these studies, histological alterations of the kidney that increased in severity with the magnitude of exposure were noted along with the dose-dependent reduction in bone volume and bone alteration. Parameters describing 
dermal absorption coefficients for various compounds have not been described although studies indicating changes in skin permeability with exposure to uranium (thereby favoring the entry of uranium into the body) have been reported. For example A. Ubios et al. [22] have determined that application of acute levels of soluble uranium compounds (i.e. $0.012 \mathrm{~g} \mathrm{U} /$ day) to the skin can significantly reduce the thickness of the epidermis $(41 \pm 14$ to $21 \pm 10 \mu \mathrm{m})$. Such thinning of the epidermis was also observed to be present 60 days after the cessation of a 31 day, daily application regime. Results of these tests were considered by the authors to be rather due to the chemical than radiological effects of uranium.

A number of experiments conducted by the various researchers showed that uranium is capable to stimulate the "oxidative damage to DNA in the absence of serious radioactive decay". In the light of another experiment provided by this group of researchers, which points to the radiological potential of uranium, which contributes to genotoxic effects in vitro, scientists noted that "so there is a temptation to expect it should be noted that the uranium can release a tumor component, both "initiating" and "developing." This possible dual role can arise, for example, as a result of the emission of alpha particles, first causing a cancer mutation (tumor initiation), then the accumulation of an oxidative damage due to the properties of heavy metals and / or radioactive uranium emissions that contribute to the spread of cancer (tumor development) or vice versa.

Descriptions of clinical cases. In this report we discuss two cases, both patients are uranium miners with giant Squamous Cell Carcinoma (SCC) and multiple lesions of Basal Cell Carcinoma (BCC) and SCC misdiagnosed for years. Both cases are from the south-western region of Kazakhstan with a desert and very hot summer climate. Both these cases concern workers of the mining and smelting combine, which includes the extraction, processing and enrichment of uranium ore. SCC of the skin is the second most common type of skin cancer and is steadily increasing in frequency. Although most cutaneous SCCs can be diagnosed early and successfully treated, in a small percentage of cases, especially if neglected, they may obtain uncontrollable growth and substantial disfigurement. Cases with giant cutaneous SCCs can be very difficult to treat and despite aggressive excision can present with the recurrence and/or metastases

Patient N, 53 y. o., miner for years in uranium mine without family history of skin cancer and long-standing tumor with the duration of 3 years and fast increasing during last period. The lesion was unsuccessfully treated as pyogenic dermatitis (misdiagnosis). General condition is satisfactory, consciousness is clear, gait is not broken. Height $-165.0 \mathrm{~cm}$, body weight $-55.0 \mathrm{~kg}$. The structure of the body is incorrect - scoliosis of the thoracic spine. Skin is pale, except the face is free from the lesions. In the left half of the face there is a large cauliflower-like bleeding tumor of irregular and sharply demarcated rolled boards measuring 16 x $14 \mathrm{~cm}$. The ulcer was extremely deep penetrating through the soft facial tissues into the temporal bone and the bony structures of the upper and lower jaw with total destruction of cheek and partially chin. Necrotic protruding mass located in the bottom was with foul smelling. This lesion was neither itchy nor painful. Regional lymph nodes were not palpable, no distant metastases were noted. Laboratory test results including complete blood cell count, urine analysis, liver function test, chest X-ray and electrocardiogram were within normal limits or negative.
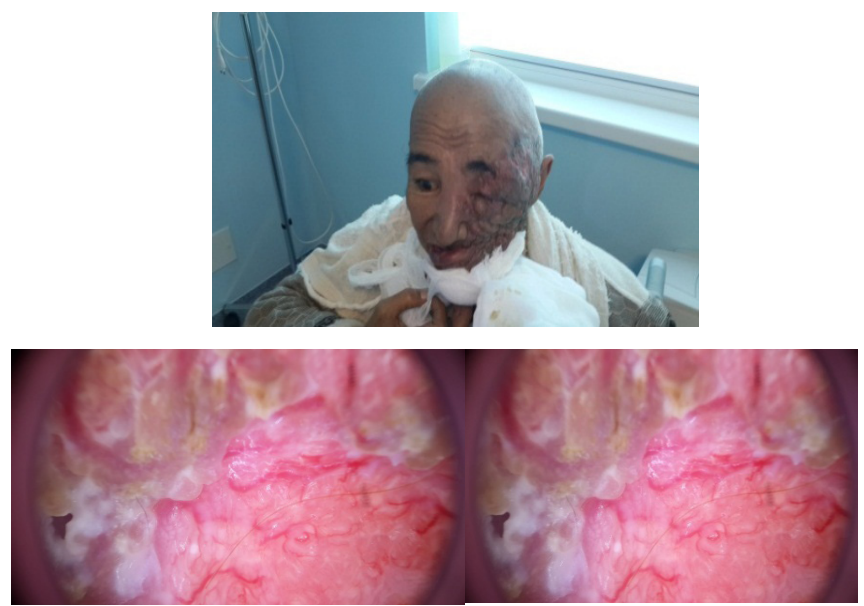

Fig. 1 .

Dermatoscopy pattern: structureless white areas which is a hallmark for squamous cell carcinoma and testifies the synthesis of large amount of keratohyalin in SCC, irregular groups of perifollicular white circles, blood spots and polymorphic vessels, mostly thick branched, sometimes looped. Incisional biopsy was performed and histopathologically was confirmed low-grade squamous cell carcinoma.

The second case is presented by 56-year- old male, also a miner in uranium mine in the past, who came to the outpatient clinic with main complaints of ulcerative tumors and growths at different locations - body, arms, scalp and ear, as well as pain and foul smelling for the last two months. Patient has history of weight loss approximately about $6 \mathrm{~kg}$ during the last 5 months. General condition is satisfactory, consciousness a clear, gait is not broken. Height $-174.0 \mathrm{~cm}$, body weight $-65.0 \mathrm{~kg}$. During the clinical examination multiple lesions on the scalp, body, ear, face and arm were found. The first tumor located on the back was developed 5 years ago, it was misdiagnosed previously and treated as chronic pyodermia. The second site was developed on the scalp 4 years ago, other lesions on the arm, cheek and ear appeared almost together during this year. They were treated as multiple sites of pyodermia. Lesions on the scalp and back were presented by solid cutaneous masses of firm consistence (fig. 1, 2) with sharply demarcated boarders. Under dermatoscopic examination in both cases the pattern of vessel arrangement was scored as radial, branched, clustered, centered, serpiginous, reticular or linear. We evaluated the presence of keratin crust/scale, central keratin mass, white circles, white pearls, white lines, white structureless areas and hemorrhage. As clue to malignance, pattern of 
white circles characteristic for squamous cell carcinoma on the background of erythema was noted. Lesions on the arm, face and ear were represented as inconspicuous areas resembling superficial scars, ill defined, with scaling and tiny erosions covered by hemorrhagic crust. Upon palpation the platelike induration extending beyond the visible margins of the lesion was felt. At the ear surface, there were the large depressed area resembling morphea, small sites of pigmentation and telangiectasia and slightly raised lateral margins with rolled boarders.
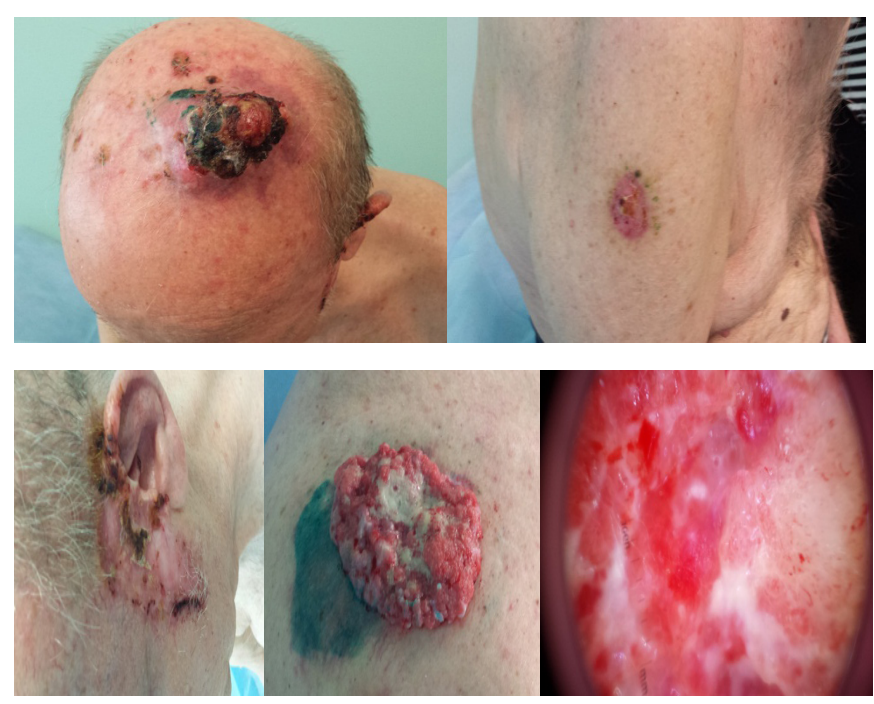

Fig. 2 .

The dermatoscopic examination has shown that the most characteristic is the pattern of blood vessels. In the cases of superficial clinical variety, the pattern of vessels was usually thin and serpentine, their arrangement in majority of cases was branchy. The polymorphous pattern of vessels represented by serpentine and coiled vessels was fixed as well. Clinical erythema during dermatoscopy was described as red or pink structureless area. In the dermatoscopic picture in case of ulcerations or erosions they were presented as structureless area often with the adherent fibers. The main additional features were randomly spaced white lines. The morphemic variety was differed with white structureless area and white lines. Dermatoscopic diagnosis of basal cell carcinomas was confirmed by morphologically.

Conclusion. Uranium mining and processing are associated with the wide range of potential adverse human health risks. The varying health risk from exposure to uranium is well established, but most of the information in the literature concerns malignant tumors of the respiratory tract thus lung is the part of the body that receives the highest dose of ionizing radiation during the exposure to uranium or its derivatives. Studies evaluating the possibility and conditions of penetration of uranium through the skin and its possible role in the development of skin malignancies have recently appeared in the literature $[21,23]$. The incidence of skin cancer among uranium miner was reported by few authors [13] and they proved that ionizing radiation can cause skin cancer, usually basal cell carcinoma and in some cases malignancy may be initiated by the ionizing radiation and promoted by ultraviolet. Two described patients who lived in the desert region with a high summer temperature and abundant solar radiation can confirm the definite dependence of the onset of skin malignancy in the interaction with two important environmental factors - uranium and ultraviolet. The risk of non-melanoma skin cancers in this group requires careful clinical and dermatoscopy monitoring and in the case of suspicious lesions special tests like histology from a skin biopsy, immunohistochemical stains and/or electron microscopy. The future study of statistical data on skin cancers from similar regions is of no less interest.

\section{References}

1. Галибин ГП, Новиков ЮВ. Токсикология промышленных соединений урана. М.: Атомиздат; 1976.184 с. (Galibin GP., Novikov JV. Toxicology of industrial composes of uranium. Moskow: Atomizdat; 1976. 184 p.) (Russian).

2. Калистратова ВС, Беляев ИК, Жорова ЕС, Нисимов ПГ, Парфенова ИМ, Тищенко ГС и др. Радиобиология инкорпорированных радионуклидов. М., 2012. С. 201-214 (Kalistratova VS, Beliaev IK, Jorova ES, Nisimov PG, Parfenova IM, Tishchenko GS et al. Radiobiology of incorporated radionucleotides. Moskow: 2012. P. 201-214) (Russian).

3. Конырова К. Казахстан вышел на первое место по добыче урана в мире (рус.). Информационное агентство TREND (30.12.2009) (Konirova K. Kazachstan now is on the first place of uranium mining in the world. Information agency TREND (30.12.2009) (Russian).

4. Кундієв ЮІ, Нагорна АМ, Варивончик ДВ. Професійний рак. Епідеміологія та профілактика. К.: Наук. думка; 2008. 336 c. (Kundiev JI, Nagorna FM, Varyvonchyk DV. Professional cancer. Epidemiology and prevention. Scientific thought. K., 2008. 336 p.) (Ukrainian).

5. DeRey BM, Lanfranchi HE, Cabrini RL. Percutaneous Absorption of Uranium Compounds. Environ Res. 1983;30:48091. https://doi.org/10.1016/0013-9351(83)90233-5

6. Domina EA, Chekhun VF. Experimental validation of prevention of the development of stochastic effects of low doses of ionizing radiation based on the analysis of human lymphocytes chromosome aberrations. Exp Oncol. 2013;35(1):65-8.

7. Eatough JP. Alpha-particle dosimetry for the basal layer of the skin and the radon progeny 218-po and 214-po. Phys Med Biol. 1997;42:1899. https://doi.org/10.1088/0031-9155/42/10/004

8. Eatough JP, Henshaw DL. Radon and thoron associated dose to the basal layer of the skin. Phys Med Biol. 1992;37:955. https://doi.org/10.1088/0031-9155/37/4/010

9. Environmental Health Perspectives. 2017. Doi: 10.1289,v.125,2017.

10. Gandini S, Sera F, Cattaruzza MS, Pasquini P, Abeni D, Boyle P et al. Meta-analysis of risk factors for cutaneous melanoma: I. Common and atypical naevi. Eur J Cancer. 2005;41:28-44. https://doi.org/10.1016/j.ejca.2004.10.015

11. Gandini S, Sera F, Cattaruzza MS, Pasquini P, Zanetti R, Masini C et al. Meta-analysis of risk factors for cutaneous melanoma: III. Family history, actinic damage and phenotypic factors. Eur J Cancer. 2005;41:2040-59. https://doi. org/10.1016/j.ejca.2005.03.034 
12. Kendall GM, Smith TJ. Doses to organs and tissues from radon and its decay products. J Radiol Prot. 2002;22:389-406. https://doi.org/10.1088/0952-4746/22/4/304

13. Kevin L, Randle H. Dermatologic surgery, Skin cancer in an atomic veteran: cause or coicidence? 2003;29(11):1100-04.

14. Krewski D, Lubin JH, Zielinski JM, Alavanja M, Catalan VS, Field RW et al. A combined analysis of North American case-control studies of residential radon and lung cancer. J Toxicol Environ Health Part A. 2006;69:533-97. https://doi. org/10.1080/15287390500260945

15. Krewski D, Jerrett M, Burnett RT, Ma R, Hughes E, Shi Y et al. Extended follow-up and spatial analysis of the American Cancer Society study linking particulate air pollution and mortality. Res Rep Health Eff Inst. 2009;140(5):5-114.

16. Krewski D, Burnett R, Jerrett M, Pope CA, Rainham D, Calle E et al. Mortality and long-term exposure to ambient air pollution: ongoing analyses based on the American Cancer Society cohort. J Toxicol Environ Health A. 2005;68(1314):1093-1109. https://doi.org/10.1080/15287390590935941

17. López R, Díaz Sylvester P, Ubios A, Cabrini R. Percutaneous toxicity of uranyl nitrate: its effect in terms of exposure area and time. Health Phys. 2000;78(4):434-7. https://doi.org/10.1097/00004032-200004000-00007

18. Marks R, Jolley D, Dorevitch AP, Selwood TS. The incidence of non-melanocytic skin cancers in an Australian population: results of a five-year prospective study. Med J Aust. 1989;150(9):475-8.

19. Monshi B, Vujic M, Kivaranovic D, Sesti A, Oberaigner W, Vujic I et al. The burden of malignant melanoma - lessons to be learned from Austria. Eur J Cancer. 2016;56:45-53. https://doi.org/10.1016/j.ejca.2015.11.026

20. Orcutt JA. The toxicology of compounds of uranium following application to the skin. Chapter 8 in: Pharmacology and Toxicology of Uranium Compounds. Voegtlin C, Hodge HC, editors. National Nuclear Energy Series VI. New York: McGraw-Hill Book Company; 1949:377-414.

21. Stearns D et al. Study may help explain link between uranium exposure and skin cancer. NAUnews. 2014. Available from: http://news.nau.edu/study-may-help-explain-link-uranium-exposure-skin-cancer/.

22. Ubios A, Marzorati M, Cabrini R. Skin alterations induced by long-term exposure to uranium and their effect on permeability. Health Phys. 1997;72(5):713-5. https://doi.org/10.1097/00004032-199705000-00006

23. Wadachi Y, Tashiro S. Skin surface contamination by uranium. J Nucl Sci Technol. 1967;4(4):50. https://doi.org/10.1080 /18811248.1967.9732726

24. Wilson J, Zuniga MC, Yazzie F, Stearns DM. Synergistic cytotoxicity and DNA strand breaks in cells and plasmid DNA exposed to uranyl acetate and ultraviolet radiation. J Appl Toxicol. 2015;35(4):338-49. https://doi.org/10.1002/jat.3015

25. Vienneau D, de Hoogh K, Hauri D, Vicedo-Cabrera AM, Schindler C, Huss A et al. Effects of Radon and UV Exposure on Skin Cancer Mortality in Switzerland. Environ Health Perspect. 2017;125(6):067009. https://doi.org/10.1289/EHP825

Стаття надійшла до редакції журналу 03.07.2018 р.

\title{
Немеланомний рак шкіри у шахтарів уранових шахт - клінічні випадки
}

\author{
Кліф Розендаль, Н. Кіладзе, Е. Шулаіа
}

Вступ. Шкідливий вплив урану на здоров’я людини добре відомий. Головним чином це стосується уражень респіраторного тракту і розвитку раку легенів. Нещодавно була висунута гіпотеза, що уран може активуватись під дією ульрафіолету, що своєю чергою може спричинити рак шкіри. Цю ідею підтверджує статистика по країнах із високим рівнем сонячної радіації та уранових депозитів, які активно розвиваються (Австралія, Казахстан, Канада, Росія та ін.). Представлено короткий огляд літератури та два випадки раку шкіри у робітників урановї шахти.

Мета. Огляд літератури щодо впливу урану й ультрафіолету на виникнення раку шкіри та опис клінічних випадків з власної практики.

Матеріали й методи. Використано контент-аналіз, метод системного й порівняльного аналізу, бібліосемантичний метод вивчення актуальних наукових досліджень. Пошук джерел здійснено в наукометричних медичних базах інформації: PubMed-NCBI, Medline, CochraneLibrary, EMBASE, ResearchGate за ключовими словами: uranium miners, non-melanoma skin cancer, UV, dermatoscopy. Для цифрової дерматоскопії використано дерматоскоп DermLite DL3, вмонтований у камеру Galaxy S-4 Samsung Corporation, а також для імерсії - гель для ультразвукового дослідження. Всі зображення оцінені згідно з алгоритмом Г. Кітлера.

Результати. Аналіз сучасних доступних літературних даних і власні клінічні випадки опосередковано підтверджують активацію похідних урану під впливом ультрафіолету та їх спільну роль у виникненні злоякісних новоутворень шкіри.

Висновки. Огляд літератури та клінічні випадки з власної практики свідчать, що видобування, обробка i збагачення урану в умовах підвищеної інсоляції пов'язані з низкою ризиків не лише для дихальної системи, але й виникнення злоякісних новоутворень шкіри. Ризик захворювання на немеланомний рак шкіри в цих групах вимагає ретельного клінічного та дерматоскопічного моніторингу, а в підозрілих випадках - біопсії, проведення імунохімічних досліджень і т. ін. Не менш цікавим $є$ вивчення статистичних показників росту онкологічної захворюваності в місцях покладів уранової руди і посиленої інсоляції.

Ключові слова: немеланомний рак шкіри, уранові шахти, інсоляція, дерматоскопія. 


\section{Non-melanoma Skin Cancers in Uranium Miners - Clinical Cases}

\section{Rosendahl, N. Kiladze, T. Shulaia}

Introduction. Using sources of ionizing radiation in various spheres of human life became an integral part of the existence of modern society and the necessary condition for further scientific and technological progress. However, along with the obvious benefits, this increases the radiation burden and number of malignant neoplasms and the related reduction in life expectancy.

The various health risks associated with uranium exposure are well known, mainly it concerns the lung cancer, but recently there has been a hypothesis that if uranium is photoactivated by ultraviolet radiation, it may be more dangerous for the skin. This idea is confirmed by statistics on countries with high levels of solar radiation and uranium deposits, which are being actively developed, such as Australia, Kazakhstan, Canada, Russia, etc. The following article provides a brief overview of the literature and presents 2 cases of basal cell carcinoma in the miners of the uranium mine.

The aim of the study. To analyze the overview of the accessible literature and the description of two clinical cases of non-melanoma skin cancers in uranium miners from the own practice.

Materials and methods. The content analysis, method of systemic comparative analysis, bibliosemantic method of studying of actual scientific researches concerning the practice of non-invasive methods of evaluation were used. The search for sources was carried out in the scientific meteorological databases: PubMed-NCBI, Medline, CochraneLibrary, EMBASE, ResearchGate by keywords: "uranium miners", "non-melanoma skin cancer", "UV", "dermatoscopy". Digital dermoscopic images were captured using dermatoscope (DermLite DL3 dermatoscope) mounted on a digital camera (Galaxy S-4 Samsung Corporation). Ultrasound gel was also used for immersion dermatoscopy. All images were evaluated using the algorithm of $\mathrm{H}$. Kittler.

Conclusions. The overview of the modern literature and clinical cases from our own practice suggest that uranium mining and processing are associated with a wide range of potential adverse human health risks and skin malignancy in this processes in not less important than of respiratory tract, especially since this risk is exacerbated by the exposure to ultraviolet light. The risk of non-melanoma skin cancers in this group requires careful clinical and dermatoscopy monitoring and in the case of suspicious lesions special tests like histology from of the skin biopsy, immunohistochemical stains and/or electron microscopy. The future study of statistical data on skin cancers from similar regions is of no less interest.

Keywords: uranium miners, non-melanoma skin cancer, UV, dermatoscopy. 